UDC 1:316.77:004

\title{
INFORMATIVE SOCIUM IN PHILOSOPHICAL DISCOURSE
}

\author{
(C) Nikitenko, Vìtalina \\ Zaporizhzhia State Engineering Academy (Zaporizhzhia, Ukraine) \\ E-mail: vitalina2006@ukr.net ORCID: 0000-0001-9588-7836 \\ (C) Maksimenyuk, Marina \\ Zaporizhzhia State Engineering Academy (Zaporizhzhia, Ukraine) \\ E-mail: marina.maximenuk@mail.com ORCID: 0000-0001-5980-5717 \\ (C) Banakh, Lyudmila \\ Zaporizhzhia State Engineering Academy (Zaporizhzhia, Ukraine) \\ E-mail: liudmylabanakh@ gmail.com, ORCID: 0000-0002-1583-2892
}

\begin{abstract}
The urgency of the study of the formation of the concept of information and communication society in the context of theoretical and methodological analysis is conditioned by the development of information and communication technologies and the Internet in the XXI century. One of the results of the development of Internet technologies is the emergence of an information and communicative society through the Internet as a social system that needs a theoretical and methodological context of measurement. In today's conditions of the information revolution, the communicative clarification of social reality, the place and role in it of the individual, the study of communicative actions and communicative competences of the individual is important. The central problem is the phenomenon of an information and communication society as a complex social phenomenon. The problem of the research is to analyze theoretical and methodological principles of the formation of the concept of an information and communication society, based on advanced information and communication technologies. Methods and approaches - synergistic, anthropological, axiological, which allowed penetrating the essence of the information and communication society, analyze the socio-anthropological, socio-economic and socio-cultural dimensions of the information and communication society. The result of the research - the modern information world, informationalism and the economy are completely dependent on networks and are created by information technologies, which in general forms an information and communication paradigm of society. Information resources are presented digitally or electronically using electronic means. Conclusion. The intensive use of information and computer technologies has been acquired at the present stage of social development of a global nature, which forms new contours of modern civilization. Information and communicative development of society as a civilizational paradigm of the XXI century forms such a kind of society, which was called the informational, determined by the informatization of life, caused by information and computer revolution.
\end{abstract}

Key words: information society, information and communicative society, information and communication technologies.

\section{The relevance of the research.}

The urgency of the study of this topic is due to the fact that in today's conditions of the information revolution there is a transition from the information society to the information and communication, which is due to the revision of the whole theoretical paradigm and model of the information society, and practical comprehension of the reality associated with the introduction the concept of information and communication management, driven by the development of information and communication technologies and the development of the Internet in the XXI century. The latter is due to the widespread dissemination and introduction of information and communication technologies, the rethinking of the theoretical foundations of the information society and the appeal of scientists to communicative approaches to the analysis of socio-political development and socio-political transformations in Ukraine, which allows us to respond to the challenges of the information age and the threat which she carries. This is due to the fact that today's information society imposes on the individual communication in any form, forcing a person to view information through the prism of an epistemological (theoretical-cognitive) role, as the avalanche increases the rapid flow of information with which a person is no longer can handle it. This is evidenced by the fact that one of the results of the development of Internet

(C) Nikitenko Vìtalina, Maksimenyuk Marina, Banakh Lyudmila, 2018 
technologies is the emergence of information and communication society through the Internet as a social system, which acts as one of the forms of formation and development of information and communication society, which requires the introduction of information and communication management. In today's conditions of the information revolution, communicative "reading" of social reality, the place and role of the individual in it, the study of communicative actions, which requires the formation of the communicative competences of the individual information and communicative society, is important because the person lives in the informational and communicative society. In today's conditions of informatization and the communicative revolution, which is a global trend, a specific mosaic culture emerges from the historical, cultural context that forms the mosaic identity that is becoming more widespread today and requires a new adaptation of man to the "ability to live" in the informationcommunicative society

\section{Problem situation.}

The problem situation arises from the fact that for the formation of the concept of information and communication society, the following components are needed: 1) electric dimension - the ability to saturate human-sized systems with the appropriate technique that facilitates access to information. When computerization focuses on the formation of technical base; 2) media dimension - the process of communicative interactions of mankind and geographic regions based on the latest information technologies; 3 ) intellectualization information management of systems of different levels of complexity; 4) the development of intellectual capital, which consists of human, organizational and consumer: a) Human capital is directly related to man and includes knowledge, practical skills, creative abilities of people, their moral values, culture of work; $b$ ) Organizational capital refers to the organization represented by the technical and software, organizational structure, patents, corporate culture; c) consumer capital, or capital relations, is formed in the process of interaction of the organization with consumers (customer databases, stable relationships with customers, etc.).

Methods and methodology. Methodology of studying the information-communicative type of society is based on methodological principles, methods and approaches developed by American scholars A. Sain and M. Nussbaum, based on basic concepts: 1) ability (capability); 2) functioning (functioning). The vector of functioning is what people can achieve in an informational (informational) society education, health, leisure activities, income, and opportunity - a set of alternative vectors of functioning in which context the individual can make a choice. Both of these indicators together imply the quality of life in the country and can serve as criteria for the development of a social market economy. Therefore, we believe that the vector of opportunities depends not only on material well-being, but also on the intellectual and psychological potential of each person, so that she appreciates, realizes all the wealth of alternatives that are open to her, and evaluates the Internet capabilities that will allow a qualitative breakthrough.

Tasks of the research: 1) to analyze theoretical and methodological principles of the concept of information and communication society, based on advanced information and communication technologies;

\section{The results of the research.}

The theoretical and methodological principles of the formation and development analysis of the informative and communication community as a society of a complex social system and interaction in Ukraine reveal the peculiarities of the information component in achieving the state's competitiveness and its impact on the civilization development of the modern world. In the conceptual paradigm of information and communicative society as a civilizational paradigm face philosophical, sociological, and managerial problems. In modern philosophic discourses, the most important place is the epistemological, ontological and axiological dimensions of the information and communication process, known as the "global revolution in communication."

Theoretical and methodological principles of research of informationcommunicative society, which will allow the theory to move, are the following methods and approaches to research:

the synergistic method allows us to analyze the global information society as a nonlinear system that develops in a nonlinear space;

the method of system and structural analysis allows us to consider the global information society as a complex social system, which has several subsystems that are constantly interacting with the environment; 
the combination of synergetic and systemic methods can explain the peculiarities of the development of the global information society in the normal and catastrophic modes;

structural-functional and institutional methods can reveal the content of political and economic changes in the global informative society;

Anthropological and social ecologic approaches are allowing to analyze socioanthropological, socio-economic and sociocultural dimensions of the global information community and information culture in the conditions of globalization.

An informative approach to the analysis of the information and communicative development of society allows us to determine the key parameters of the informational movement of states in order to promote them to highly developed models of this type of society that allows strengthening the state of the country as criteria for informatization. It is an informative approach which allows you to provide the necessary option to advance the country forward. The underestimation of the informational approach for all countries, without exception, plays a negative role. The information level should engage with the political and state level in order to provide the country with the advancement of one stage of development of the society - industrial or post-industrial to informational, knowledgeable.

Informatization is structured by countries with human development indices, which includes informatization, making optimum transition to the highest level or model of development. The informational approach to the analysis of the informational and communicative development of society as a civilizational paradigm of the 21 st century proceeds from a synergistic, "nonlinear" vision of the solution of general civilizational problems. Their solution is based on the transition to a new model for the development of modern society, in which man is opposed to nature, the "machine world" - to the "natural", to a co-evolutionary model of their existence and interaction.

The synergistic approach should also be related to the integrated consideration of the links of the communication system, which increases their integrity, promotes efficiency and the possibility of their more effective development. Both informational and synergetic approaches provide an opportunity to understand the rational-design basis of society, which contributes to the formation of the integrity of the world.

However, the chaotic side (destructive) actively influences the first, stimulating the search for more effective structures, improving organizational reconstruction and strengthening the interaction between all spheres of life. This new significant informational factor combined with synergy in the near future will change the world through which changes will occur in the economy, society and culture, "said M. Castells. Both informational and synergetic approaches lead to an understanding of the informational and communicative unity of the world as a civilizational paradigm of the 21st century, which generates self-organizing system, - notes V. Maturana.

At the same time, not only the communication bases of the organization of society, but also the forms and types of social communication that transform the tendency of the transformation of its structure in the postindustrial era transform. This refers to the change in the classical models of information and communication development of society as a civilizational paradigm of the 21st century, which has two fundamental processes - the process of production and the process of information functioning and the process of social interaction (social communication). Social communication should be understood as a synergy of information based on reason, science, culture. In the first case, there is an active displacement from the sphere of human activity of subject relations (the real world of things), their replacement by "artificial intermediaries", and in the second case there is a tendency to symbolize the person himself, displacement of it, at best, a virtual subject. This problem, as A. Lazarevich remarks, has at least two levels.

The first level involves the recognition of truth, the essence of which will be difficult. This problem causes a new spectrum of problems that relate to the sphere of interaction of human knowledge and consciousness with similar information systems. On this basis, it is difficult to expect the formation of stable, and most importantly - the true mental meanings, which is the norm of human reflection and world outlook in general.

The second level of the problem of information security involves the manipulation of information in order to influence the consciousness of man $[8$, p. 7]. In the context of the development of information and communicative society, first and foremost,

(C) Nikitenko Vìtalina, Maksimenyuk Marina, Banakh Lyudmila, 2018 
information-communicative reproductions of the symbolic world are used through mediation of images and symbols.

The conceptualization of information and communication society means the selfdeployment of the space of the world, man and society through the prism of informatization and communication, which are the mediators of the formation of the information and communication mechanism of contemporary society, but this society should be developed, investing in highvalue spheres of its rise, based on higher technological settings.

To develop the concept of an information and communication society it is necessary: the creation of a nationwide automated system; development of telecommunication infrastructure and creation of access points for open information systems; the development and improvement of ICT and the formation of an export-oriented industry of the IT industry; improvement of the legislative base and the system of state regulation in the field of informatization; improvement of activity of public administration and administration bodies on the basis of ICT use; development of informatization processes in sectors of the real economy, including creation of the system of electronic trade and logistics; development of the system of training and retraining of specialists on ICT and skilled users; promoting the development of culture and the media through ICT; improvement of information security system in the context of phased implementation of program tasks; development of new socio-technological institutes: telemedicine and distance education, ecommerce and distance employment, Internet media and e-government.

Characteristic attributes of the concept of information and communication society are:

increasing the role of information and knowledge in the life of society;

an increase in the share of information communications, products and services in the gross national product;

creation of a global information and communication space, providing effective information interaction between people; - their access to world information resources; satisfaction of their needs in information services.

The purpose of information and communication management is the creation of an informational and communicative society that arose in the late 60's and early 70's, based on the gradual disappearance of routine labor and the replacement of it with creative (cognitive) work.

The most relevant ideas that contributed to the emergence of the concept of information and communicative society are: technetronic civilization is replaced by anthropogenic (G. Diligensky); "The end of history has come", that is, the post-historical period began (F. Fukuyama); the birth of a "multidimensional person" of post-industrial civilization (G. Marcuse); "Revolution in the field of the human psyche" (R. Beck), within which there are three revolutions: 1) scientific and technical (material); 2) social; 3) psychic. Conceptuallycategorical apparatus for analyzing information and communication society is reduced to the following:

Internet is a global information system that is logically linked to the global address space and is based on Internet protocols defined by international standards.

Information system of general access - is a set telecommunication networks and means for the accumulation, processing, storage and transmission of data.

Informative security of telecommunication networks - the ability of telecommunication networks to provide protection against destruction, distortion, blocking of information, its unauthorized release or breach of established order.

Informative - information provided in the form of signals, signs, sounds, moving or still images, or otherwise.

Telecommunication provider - is a business entity that has the right to carry out activities in the field of telecommunications without the right to maintain and operate telecommunication networks and to provide telecommunication channels [10].

All these problems lie in the formation of the concept of information and communication society, which should be limited to two values: 1) information management - information flows and information resources, that is, automated technology of information processing in a particular subject area; 2) management with the help of information, that is, management technology, management in its own sense of the word. In this context, information and communication management involves the achievement of several related disciplines in relation to the management of information in organizations as complex socio-technological systems, which allows in practice to move to the information-oriented type of organization, 
characteristic of the information-communicative type of society.

The specialist in the information society and the Internet era should be determined by a techmultinational (informational) culture, rooted in the world of research. This is a culture of faith in the natural strength of scientific and technological development as a key component of human progress. We emphasize 10 principles of training human resources for work in the information society, which is high-tech: 1) competition of working personnel; 2) competition of management personnel; 3) competition of business reputation and initiative; 4) competition of achievements; 5) multidisciplinary competition; 6) quality competition; 7) competition of products; 8) competition of information support; 9) competition of forms of sales; 10) competition of financial and resource services, etc.

The global information society manager must be prepared for globalization of business strategies in a variety of markets. Therefore, universities should prepare a global manager, strengthen the role of information skills, management of creativity and promote the formation of information worldview and information culture. Western managers often refer to the organization's structure as key factors of success, having its own logic of development, the impact of information and communication management on the development of an organization as a complex socio-technological system in the conditions of the stochasticity(стохастичності) of the information society and network economy. All these features characterize European management in the modern era of the development of information and communication society. To this end, a professional specialist must acquire the terminology of a global information society in which to live and manage. Communicating society means a radical change in the structure and nature of social development, the development and introduction of new types of information exchange, which requires a new spiral in the development of information technology and contributes to the formation of a new type of information and communication life.

In the context of different philosophical traditions, we highlight the features of the concept of information and communication society, which is based on the informationalcommunicative space, which needs to streamline the gradual development of information production and the vital functions of social agents of information as actors of the information society. An attempt to adequately describe and interpret radical changes in the structure of the economy, politics, and culture have become systematic and purposeful in the twentieth century, - notes A. Zelenkov. Therefore, the main advantage of the concept of an information and communication society - in the development of innovative active strategies, based on which increase the share of knowledge in the structure of added value of products, which should bring more revenue for Ukraine in order to solve longterm and short-term tasks of the economy.

Proceeding from the foreseeable development of the fourth sector of the economy related to the production, distribution and transmission of information, we will draw conclusions on changes in the structure of economic production, the reduction of the cost of electronic communications was predicted the development of new forms of employment and political activity, changes in the media and leisure activities. With the widespread spread of e-mail technologies, and then Internet predictions that were "futurological", they moved into a practical application, even at the level of economic planning and programming.

The intensive use of information and computer technologies has become at the present stage of social development of a global nature that the term "globalization" has begun to bind many authors to the inherently peculiar information and computer revolution, that is, to identify and place an equal sign between them. It is no coincidence that globalization is interpreted as a process of rapid formation of a single global financial and information space on the basis of mainly high-tech-computer technologies. It is almost impossible to know the informational and communicative development of contemporary society caused by the processes of globalization, as global processes are associated with the development of information and communication technologies that accelerate economic development and contribute to strengthening the information society and innovative development of the country.

Informational and communicative development of society as a civilizational paradigm of the 21 st century includes the development of civilization, and above all economic and cultural, which contributes to the improvement of society through the development of information. Modern civilization is characterized by an increase in the role of

(C) Nikitenko Vìtalina, Maksimenyuk Marina, Banakh Lyudmila, 2018 
information as the leading force of the information society, which in the scientific world was called "informational".

The modern information world, informationalism, and economics are completely dependent on networks and are created by information technologies, which in general form an information and communication paradigm of society. Information resources are mainly represented digitally or electronically via electronic means (Internet, e-mail, video telephony, videoconferencing, facsimile, etc.). The intensive use of information and computer technologies has been acquired at the present stage of social development of a global nature, which forms new contours of modern civilization. The informational and communicative development of society as a civilizational paradigm of the 21 st century forms such a kind of society, which was called the informational, determined by the universal and universal informatization of life, caused by the information and computer revolution.

Informative industrialization that arose at this stage was ahead of the number of employed workers, demand and supply of information services, which in general led to an "information explosion", which in turn led to the "information revolution". The informational approach to the analysis of information and communication the development of society as a civilizational paradigm makes it possible to enhance the opportunities that a country or organization owns in a competitive environment that develops informatization that has become prevalent today for the whole world. Today, this environment is formatted in the context of informatization and communication, which creates the foundations of the development of the info-communication community. It is information that manifests itself most clearly in dynamic conditions, in the face of collisions of various models of information society, which is the usual scheme of interaction in the modern world: from the competitive struggle of the two firms to the competitive struggle of two states. Unfortunately, after Ukraine became independent, it used perhaps the worst possible model for transforming the economy and society compared to other postsocialist countries. Instead of evolutionary development in line with consistent national policy, the country "pulled" into the phase of spontaneous primary accumulation of capital inherent in "wild capitalism.

\section{Conclusion}

Practice shows that humanity is on the verge of "information explosion" only because for the first time in the history of mankind there was a situation where the world was in a situation of survival and spiritual disaster, which raises questions to the fundamental traditional conceptual schemes and models of organizations. The socio-philosophical perspective of the study of the informationcommunicative society as a complex social system and interaction has a special meaning, since it is aimed at using a synergistic approach to the analysis of the information and communication development of society as a civilizational paradigm of the 21 st century, as the synergy in society increases as a result of the complication of the system of production forces It generates the emergence of new elements (in particular, information, knowledge), their complex interaction, the emergence of more perfect relations, based on the information basis and contribute to the optimal combination of advanced forms of human coexistence, demonstrating the basic forms and methods of social transformation. However, in Ukraine, such negative factors as lack of a strategic vision of transformation in the country, insufficiency and inefficiency of reforms, growing corruption, inefficiency and incompetence of public administration, and extremely unsuccessful fiscal policies became apparent.

It is about the formation of the concept of information and communicative society as a civilization paradigm for the development of modern Ukrainian society in a globalized world. In recent years, the situation in Ukraine has radically changed: the intellectually capacious sectors of the domestic economy have almost completely degraded; demand in the labor market was mainly shifted to service providers, where practically unnecessary complex knowledge-intensive knowledge for creating a new one was needed, and only knowledge of the subject area, certain skills and practical experience was needed. Under such conditions, the field of advanced education, science and innovation, especially in the fundamental-natural component, began to "disturb" the labor market and the new information society.

Information resource is the basis of information-analytical and forecast activity. At present, information resources, both published and unpublished, are created and accumulated by ministries, state committees, departments, scientific and research organizations and 
institutions in accordance with the directions of their activities. Such autonomous formation of sectorial (specialized) information systems and resources focuses on the solution of departmental tasks and does not facilitate the pooling of these resources in the national fund. The resources that reflect the results of scientific and technical activities of scientific institutions, enterprises, organizations are left out of focus and insufficiently used. It is necessary to conceptualize with the formation of national information resources of scientific and technical information in order to provide broad access to users.

Gradually, we become integrated (involved) in the process of informatization and involuntarily become owners of various network cards, visitors to the network of salons, too many use the Internet, mobile and other types of communication. All this seems natural today.
However, lowering the quality of human capital preparation directly affects the loss of competitiveness of the country in the world. Production in Ukraine of high-tech products, which was created on the basis of high-level knowledge, and its export for 10 years decreased from $5.5 \%$ to $3.5 \%$, while, for example, for China this indicator for the same period of time has increased almost twice - from 18 to $33 \%$. Based on $95 \%$ in the third and fourth technological processes, the economy of Ukraine worked at a profitability of $3-6 \%$ and created approximately one or two orders of magnitude lower the innovative component of this cost per unit of output compared with the economies of the fifth and sixth modes that dominate the world (radio electronics, computing, telecommunication technology, software, robotics, information services, biomedical engineering).

\section{Список использованных источников}

1. Andriukaitiene, Regina, Voronkova, Valentyna, Kyvliuk, Olga, Maksimenyuk, Marina and Aita, Sakun (2017). Theoretical insights into expression of leadership competencies in the process of management. Problems and Perspectives in Management, 15(1-1), 2017. P. 220-226. http://dx.doi.org/10.21511/ppm.15(1-1).

2. Voronkova, V., Maksimenuyk, M., Nikitenko V. Humanistic management in the context of philosophic anthropology: human dimension / V. Voronkova, M. Maksimenyuk, V. Nikitenko // IntellectualArchive Vol. 5, No. 1, January 2016. P. 37-48.

3. Воронкова, В.Г., Нікітенко, В.О. Сучасна геокультура як соціокультурний феномен культурної глобалізації // Гілея: К: «Видавництво «Гілея», Вип. 72. 2013. С.487-492.

4. Воронкова, В.Г. Формування синергетично-рефлексивної моделі самоуправлінського суспільства: цивілізаційний контекст // Гуманітарний вісник Запорізької державної інженерної академії: збірник наукових праць. Запоріжжя: ЗДІА. Вип.49. С.17-28.

5. Кивлюк, О.П. Глобалізація та інформатизація освіти в предметному полі філософії освіти // Гуманітарний вісник Запорізької державної інженерної академії: збірник наукових праць. Запоріжжя: ЗДІА. 2014. Вип.57. С.192-200.

6. Кравченко, I.М. Аналіз категорій трудовий потенціал в контексті категорый робоча сила, людський потенціал, людський капітал та трудові ресурси // Гуманітарний вісник Запорізької державної інженерної академії: збірник наукових праць. Запоріжжя: ЗДІА. Вип. 51. 2012. С.124-131.

7. Максименюк М. Ю., Нікітенко В.О. Інформаційно-комунікативне суспільство як різновид складної соціальної системи і взаємодії // Гуманітарний вісник Запорізької державної інженерної академії: [зб.наук.пр.] Запоріжжя: Вид-во ЗДІА, 2016. Вип. 66. С. 266-278

8. Нікітенко В. О. Сучасна геокультура як соціокультурний феномен // Гуманітарний вісник Запорізької державної інженерної академії, Вип.53. 2013. С. 261-270.

9. Nikitenko Vitalina. Cultural and social competence creation in the process of English language study: information society aspect // Humanitarian Bulletin of Zaporizhzhia State Engineering Academy. Issue. 2016. 251-257.

10.Олексенко, Р. І. Вплив комунікацій на ціннісні орієнтири особистості // Гуманітарний вісник Запорізької державної інженерної академії. Вип. 62. 2015. С. 65-73.

11. Олексенко, Р. И. Философия образования как неотъемлемый фактор экономического развития общества // Социосфера. № 3. 2013. С. 19- 26

12. Олексенко, Р. І., Молодиченко, В. В. Концептуальні пріоритети формування сучасної людини економічної / Р. І. Олексенко, В. В. Молодиченко // Гуманітарний вісник Запорізької державної інженерної академії. Вип. 70. 2017. С. 164 - 175

13. Пунченко, О.П., Лазаревич, А.А. Інформатизація як засіб репрезентації інформаційних ресурсів суспільства // Гуманітарний вісник Запорізької державної інженерної академії : [зб. наук. праць]. Запоріжжя : Вид-во ЗДІА. Вип. 63. 2015. С. 21-30.

14.Соснін, О.В., Кононець, М.О. Нові інформаційно-технологічні реалії комунікації в науковоосвітній діяльсноівті як запорука інноваційного розвитку суспільства: колективна монографія //

(C) Nikitenko Vìtalina, Maksimenyuk Marina, Banakh Lyudmila, 2018 
Інформаційне суспільство в світі та Україні: проблеми становлення та закономірності розвитку / За ред. д.філософ.н., проф. В.Г.Воронкової; Запоріз. держ. інж. акад. Запоріжжя: ЗДІА. 2017. С.120-140.

15. Утюж, І.Г. Цивілізаційенна парадигма освіти: теоретико-методологічяний аспект // Гуманітарний вісник Запорізької державної інженерної академії : [зб. наук. праць]. Запоріжжя : Вид-во ЗДІА. Вип. 38. 2009. C. 60-66.

\section{REFERENCES}

1. Andriukaitiene, Regina, Voronkova, Valentyna, Kyvliuk, Olga, Maksimenyuk, Marina and Aita, Sakun (2017). Theoretical insights into expression of leadership competencies in the process of management. Problems and Perspectives in Management, 15(1-1), 220-226. http://dx.doi.org/10.21511/ppm.15(1-1) [in English].

2. Voronkova, V., Maksimenyuk,, M., Nikitenko V. (2016 a). Humanistic management in the context of philosophic anthropology: human dimension // IntellectualArchive Vol. 5, No. 1, January 2016. 37-48 [in English].

3. Voronkova, V.G., Nikitenko, V.O. (2013 b). Modern geokultura as a sociocultural phenomenon of cultural globalization // Gileâ: "Publisher hileya». Issue. 72. 487-492 [in Ukrainian].

4. Voronkova, V.G. (2012 c). Formation of synergistically-reflexively model samoupravlìnskogo society: the civilizational context // Humanitarian Bulletin of Zaporizhzhia State Engineering Academy: scientific papers. Zaporozhye: ZDIA. Issue 49, 17-28 [in Ukrainian].

5. Kyvliuk, O. P. (2014). Globalization and Informatization of education in the subject field of the philosophy of education // Humanitarian Bulletin of Zaporizhzhia State Engineering Academy: scientific papers. Zaporozhye: ZDIA. Issue 57, 192-200 [in Ukrainian].

6. Kravchenko, I. M. (2012). An analysis of the categories of employment potential in the context of the kategoryj workforce, human potential, human capital and human resources // Humanitarian Bulletin of Zaporizhzhia State Engineering Academy: scientific papers. Zaporozhye: ZDIA. Issue. 51. S. 124-131 [in Ukrainian].

7 Maksimenûk M. Yu., Nikitenko V. O. (2016). Informational and communicative society as a kind of complex social systems and interaction // Humanitarian Bulletin of Zaporizhzhia State Engineering Academy. Zaporozhie: publishing ZDIA. Issue. 66. 266-278 [in Ukrainian].

8. Nikitenko V. O. (2013). Modern geokultura as a sociocultural phenomenon // Humanitarian Bulletin of Zaporizhzhia State Engineering Academy. Issue 53. 261-270 [in Ukrainian].

9. Nikitenko Vitalina (2016). Cultural and social competence creation in the process of English language study: information society aspect // Humanitarian Bulletin of Zaporizhzhia State Engineering Academy. Zaporozhie: publishing ZDIA. Issue. 251-257 [in Ukrainian].

10. Oleksenko, R.I. (2015a). The impact of communications on the value guidance of personality // Humanitarian Bulletin of Zaporizhzhia State Engineering Academy. Issue. 62.C. 65-73 [in Ukrainian].

11. Oleksenko, R.I.. (2013b). Filosofiâ obrazovaniâ as neotemlemyj factor èkonomičeskogo development society // Sociosfera. № 3. 19-26 [in Russian].

12. Oleksenko, R.I., Molodičenko, V.V. (2017d). Conceptual priorities formation of the modern human economic // Humanitarian Bulletin of Zaporizhzhia State Engineering Academy. Issue. 70. 164-175 [in Ukrainian].

13. Punčenko, O.P., Lazarevich A.A. (2015). Informatization as a means of disseminating the information resources of the society // Humanitarian Bulletin of Zaporizhzhia State Engineering Academy: [GS Sciences works]. Zaporozhye: publishing ZDIA. Issue. 63. 21-30 [in Ukrainian].

14. Sosnin, O.V., Kononec, M.O. (2017). New information and technological realities of communications in the scientific-educational diâlsnoìvtì as the key to innovative development: collective monograph // Information society in the world and in Ukraine: problems of establishment and regularities of development / Ed. d. philosopher, Prof. G. Voronkovoï; Zaporìz. State. ing. teaching. Zaporozhye: ZDIA. 120-140 [in Ukrainian].

15. Utûž, I.G. (2009). Civììzacìjenna paradigm of education: theoretical-metodologičânij facet // Humanitarian Bulletin of Zaporizhzhia State Engineering Academy: [GS Sciences works]. Zaporozhye: publishing ZDIA. Issue. 38. 60-66 [in Ukrainian].

Нікітенко В. О. - Запорізька державна інженерна академія (Запоріжжя, Україна)

E-mail: vitalina2006@ukr.net ORCID: 0000-0001-9588-7836

Максименюк М. Ю. - Запорізька державна інженерна академія (Запоріжжя, Україна)

E-mail: marina.maximenuk@mail.com ORCID: 0000-0001-5980-5717

Банах Л. С. - Запорізька державна інженерна академія (Запоріжжя, Україна) E-mail: : liudmylabanakh@gmail.com, ORCID: 0000-0002-1583-2892 


\section{ІНФОРМАЦЙНИЙ СОЦІУМ У ФІЛОСОФСЬКОМУ ДИСКУРСІ}

Анотація. Актуальність дослідження формування концепції інформаційно-комунікаційного суспільства в контексті теоретико-методологічного аналізу зумовлено розвитком інформаційнокомунікативних технологій та мережі Інтернет у XXI столітті. Одним з результатів розвитку інтернеттехнологій $\epsilon$ виникнення інформаційно-комунікативного суспільства завдяки мережі Інтернет як соціальної системи, що потребує теоретико-методологічного виміру. В сучасних умовах інформаційної революції важливим $є$ комунікативне прояснення соціальної реальності, місця і ролі в ній індивіда, вивчення комунікативних дій та комунікативних компетентностей індивіда. Центральною проблемою $\epsilon$ феномен інформаційно-комунікаційного суспільства як складного соціального феномена. Завдання дослідження - проаналізувати теоретико-методологічні засади формування концепції інформаційнокомунікативного суспільства, що базується на передових інформаційно-комунікативних технологіях. Методи і підходи - синергетичний, антропологічний, аксіологічний, що дозволили проникнути в сутність інформаційно-комунікаційного суспільства, проаналізувати соціо-антропологічні, соціоекономічні та соціокультурні виміри інформаційно-комунікаційного суспільства. Результат дослідження - сучасний інформаційний світ, інформаціоналізм та економіка повністю $є$ залежними від мереж і створюються інфо-технологіями, що в цілому формують інформаційно-комунікаційну парадигму соціуму. Інформаційні ресурси представлені у цифровому чи електронному вигляді здійснюються за допомогою електронних засобів. Висновок. Інтенсивне використання інформаційно-комп'ютерних технологій набуло на сучасному етапі соціального розвитку глобального характеру, що формує нові контури сучасної цивілізації. Інформаційно-комунікативний розвиток соціуму як цивілізаційна парадигма XXI століття формує такий вид соціуму, який отримав назву інформаційного, детермінованого інформатизацією життя, викликаного інформаційно-комп'ютерною революцією.

Ключові слова: інформаційне суспільство, інформаційно-комунікаційне суспільство, інформаційнокомунікаційні технології

Никитенко В. А. - Запорожская государственная инженерная академия (Запорожье, Украина) Еmail: vitalina2006@ukr.net, ORCID: 0000-0001-9588-7836

Максименюк М. Ю. - Запорожская государственная инженерная академия (Запорожье, Украина) Еmail: marina.maximenuk@mail.com, ORCID: 0000-0001-5980-5717

Банах Л. С. - Запорожская государственная инженерная академия (Запорожье, Украина) E-mail: : liudmylabanakh@gmail.com, ORCID: 0000-0002-1583-2892

\section{ИНФОРМАЦИОННЫЙ СОЦИУМ В ФИЛОСОФСКОМ ДИСКУРСЕ}

Аннотация. Актуальность исследования формирования концепции информационнокоммуникационного общества в контексте теоретико-методологического анализа обусловлено развитием информационно-коммуникационных технологий и сети Интернет в XXI столетии. Одним из результатов развития интернет-технологий есть возникновение информационно-коммуникационного общества благодаря сети Интернет как социальной системы, которая требует теоретико-методологического измерения. В современных условиях информационной революции важным есть коммуникативное прояснение социальной реальности, места и роли в ней индивида, изучения коммуникационных действий и коммуникационных компетентностей индивида. Центральной проблемой есть феномен информационно-коммуникационного общества как сложного социального феномена. Задачи исследования - проанализирвоать теоретико-меитодологические основания формирования концепции информационно-коммуникационного общества, которое базируется на передовых информационнокоммуникационных технологиях. Методы и подходы - синергетический, антропологический, аксиологический, которые позволили проникнуть в сущность информационно-коммуникационного общества, проанализирвоать социо-антропологические, социо-экономические и социокультурные измерения информационно-коммуникационного общества. Результат исследования - современный информационный мир, информационализм и экономика полностью зависимы от сетей и создаются инфотехнологиями, которые в целом формируют информационно-коммуникационную парадигму социума. Информационные ресурсы представлены в цифровом и электронном виде осуществляются при помощи электронных средств. Вывод. Интенсивное использование информационно-компьютерных технологий приобрело на современном этапе социальное равзитие глобального характера, чтио формирует новые контуры современной цивилизации. Информационно-коммуникационное развитие социума как цивилизационной парадигмы XXI стоелтия формирует такой вид соцума, который получил название информационного, детерминированного информатизацией жизни, вызванным информационнокомпьютерной революцией.

Ключевые слова: информационное общество, информационно-коммуникационное общество, информационно-коммуникативные технологии

Стаття рекомендована до публікації д.філософ.н., проф. Пунченко О.П. (Одеса, Україна)

(C) Nikitenko Vìtalina, Maksimenyuk Marina, Banakh Lyudmila, 2018 
Надійшла до редколегії: 14.03 .18 р. Прийнята до друку: 19.03 .18 р.

Нікітенко Віталіна Олександрівна, кандидат філософських наук, доцент, доцент кафедри філософії та суспільних наук, Запорізька державна інженерна академія (Запоріжжя, Україна), проспект Соборний, 226, Запоріжжя 69006 Україна.

E-mail: vitalina2006@ukr.net, ORCID 0000-0001-9588-7836

Максименюк Марина Юріївна, кандидат філософських наук, доцент кафедри менеджменту організацій та управління проектами, Запорізька державна інженерна академія (Запоріжжя, Україна), проспект Соборний, 226, Запоріжжя 69006 Україна.

E-mail: marina.maximenuk@mail.com ORCID: 0000-0001-5980-5717

Банах Людмила Степанівна, старший викладач кафедри філософії та суспільних наук, Запорізька державна інженерна академія (Запоріжжя, Україна),

проспект Соборний, 226, Запоріжжя 69006 Україна.

E-mail: liudmylabanakh@gmail.com, ORCID: 0000-0002-1583-2892 